David R. Bevan MH MRCP FFARCS, François Donati PH D MD

\title{
Editorial Anticholinesterase antagonism of succinylcholine phase II block
}

Clinical control of neuromuscular blockade (NMB) has been simplified by train-of-four monitoring. ' It allows the depolarizing NMB of succinylcholine to be differentiated from the non-dcpolarizing block of the competitive muscle relaxants and is preferable to tetanic stimulation which partially antagonizes non-depolarizing NMB. The competitive relaxants demonstrate fade in the force of muscle contraction to train-of-four stimulation and, of course, can be antagonized with anticholinesterase agents. Thus, it is tempting to assume that the presence of train-offour fade predicts the reversibility of a NMB with either neostigmine or edrophonium. This is not always true: the slight fade seen when enflurane is administered at high concentration in the absence of non-depolarizing blocking drugs is not influenced by anticholinesterases. ${ }^{2}$ More important, can anticholinesterases antagonize the phase II block of succinylcholine?

Prolonged exposure of the neuromuscular junction to succinylcholine alters the nature of the NMB. The initial phase I block changes to phase II, "non-depolarizing," block which is characterized by fade in response to train-of-four or tetanic stimulation and the NMB can often but not always be antagonized with anticholinesterases. ${ }^{3}$ Prolonged exposure may occur either with lengthy administration, e.g., succinylcholine infusion, or by decreased metabolism, e.g., atypical cholinesterase. Although the response to train-of-four stimulation is similar in both situations the consequences of anticholinesterases are different.

From the Departments of Anaesthesia, Royal Victoria Hospital \& McGill University, 687 Pine Avenue West, Montreal, Quebec, H3A IA1.
When succinylcholine is given by infusion to maintain $80-90$ per cent NMB, phase II block, defined as a train-of-four ratio (T4/T1) of $<0.5$, can be recognized after approximately $3 \mathrm{mg} \cdot \mathrm{kg}^{-1}$ and sooner in the presence of volatile anaesthetio agents. ${ }^{4-6}$ Most patients who have received succin$y$ lcholine to a total dose of less than $7 \mathrm{mg} \cdot \mathrm{kg}^{-1}$ over less than one hour demonstrate rapid recovery of neuromuscular acrivity after stopping the infusion so that $\mathrm{T} 4 / \mathrm{T} 1$ is restored to more than 0.7 within ten minutes and this is associated with resumption of spontaneous respiration. The rate of recovery after stopping the infusion is slower after larger doses and correlates with the dose and time of exposure to succinylcholine. ${ }^{4-6}$ However, recovery can be accelerated with either neostigmine or edrophonium. Indeed, the study in the present issue of the journal suggests that if 80-90 per cent NMB is maintained for up to three hours with infusions of either pancuronium or succinylcholine and if atropine and neostigmine, $35 \mu \mathrm{g} \cdot \mathrm{kg}^{-1}$, are given ten minutes after stopping the infusions then neuromuscular activity returns more rapidly in patients given succinylcholine than pancuronium. ${ }^{7}$

Conversely, there are several reports of prolonged NMB after succinylcholine in patients homozygous for atypical cholinesterase in whom the appearance of the block resembles phase $I I, i . e .$, the $T 4 / T 1$ is $<0.5$, but the NMB is antagonized only partially or not at all by neostigmine or edrophonium. ${ }^{8-10} \mathrm{Can}$ these observations be explained and what recommendations can be made for safe clinical practice?

Anticholinesterases have three effects on succinylcholine-induced NMB. They potentiate phase $I^{11}$ and antagonize phase II blocks ${ }^{4-6}$ and also delay succinylcholine metabolism by inhibiting plasma cholinesterase. ${ }^{12}$ The predominant action in any 
particular situation will depend upon the characteristics of the NMB and the presence or absence of circulating succinylcholinc. Thus, a phase I block which occurs early after the administration of succinylcholine and is associated with high plasma concentrations will be potentiated by anticholinesterases as a result of increased depolarization and its duration will be prolonged because of plasma cholinesterase inhibition. Conversely, the phase II block which persists ten minutes or more after stopping a prolonged succinylcholine infusion is associated, in normal patients, with low plasma concentrations of succinylcholinc and can be antagonized rapidly with anticholinesterases. However, the phase II block associated with atypical cholinesterase is quite different because plasma concentrations remain elevated. Thus, although the phase II block may be antagonized, any persisting phase I block will remain and may be potentiated by anticholinesterases and the already diminished metabolism of succinylcholine will be decreased further. A beneficial effect of anticholinesterase in succinylcholine apnoea is apparent only if given when spontaneous recovery is almost complete. Recovery from the block can be accelerated with human cholinesterase. ${ }^{13}$ A purified preparation is available in Europe but not in North America. However, plasma cholinesterase activity is preserved in bank blood stored in $\mathrm{CPD}^{14}$ so that one to two units of blood or plasma should be effective in restoring succinylcholine hydrolysis, although the risks of transfusion should be weighed against the consequences of two to three hours of ventilatory support.

A nerve stimulator is essential in the clinical management of these succinylcholine NMB's, preferably one with the option of train-of-four stimulation. Anticholinesterase can be given after succinylcholine infusion if there is obvious fade ten minutes after stopping the infusion. Usually, neuromuscular activity is restored with small doses, neostigmine I-2 $\mathrm{mg} \cdot 70 \mathrm{~kg}^{-1}$ or edrophonium $10-20 \mathrm{mg} \cdot 70 \mathrm{~kg}^{-1}$ which can be repeated as long as some improvement is observed. Used in this way we have always seen recovery of function. Also, it has been suggested that if tetanic stimulation is applied and followed by post-tetanic facilitation then this is a good predictor of anticholinesterase reversibility after succinylcholine phase II NMB. ${ }^{15,16}$ Anticholinesterases should not be given without human cholinesterase in an attempt to restore neuromuscular activity in patients with deficient or abnormal plasma cholinesterase. The treatment of choice remains controlled ventilation and general support of these patients, during the period of time required for the return of normal neuromuscular function.

\section{L'antagonisme du bloc de phase II de la succinylcholine par les anti- cholinestérasiques}

L'utilisation du train-de-quatre stimulations a simplifié l'évaluation clinique de l'intensité du blos neuromusculaire.' Ce procédé permet de différencier le bloc dépolarisant de la succinylcholine du bloc non-dépolarisant des curares à action compétitive, tout en évitant la stimulation tétanique, qui produit un antagonisme partiel du bloc non-dépolarisant. En présence d'un curare non-dépolarisant, Ja réponse au train-de-quatre stimulations se caractérise par un épuisement et les anticholinestérasiques peuvent antagoniser le bloc neuromusculaire. On est alors tenté de présumer que la présence d'un epuisement suite à une stimulation par un train-dequatre puisse prédire la possibilité d'antagonisme du bloc par la néostigmine ou l'édrophonium. Ceci n'est pas toujours le cas: en présence des concentrations élevées d'enflurane et sans curares, on observe un épuisement qui n'est pas affecté par les anticholinestérasiques. ${ }^{2}$ Par contre, pouvons-nous utiliser les anticholinestérasiques pour antagoniser le bloc de phase Il produit par la succinylcholine?

La présence de succinylcholine à la jonction neuromusculaire produit, avec le temps, un changement de type de bloc, Le bloc de phase I se transforme en un bloc de phase II ("non-dépolarisant"). Ce dernier se caractérise par un épuisement lorsqu'une stimulation de train-de-quatre ou une stimulation tétanique est appliquée. Ce bloc peut être antagonisé par des anticholinestérasiques. ${ }^{3}$ 